\title{
The Use of Technology Improves the Sales Value of Farmers
}

\author{
Khairuman ${ }^{1}$ and Herry Setiawan ${ }^{2}$ \\ 1,2 Program Studi Dilploma III Teknik Komputer, Politeknik Aceh Selatan \\ Jl. Merdeka, Komplek Reklamasi Pantai, Tapaktuan 23751, Aceh Selatan, Indonesia \\ E-mail: chairumanmonev@yahoo.com
}

ARTICLE INFO

Article history:

Accepted

Keywords:

Sales, Farmer's harvest

farmer contribution

\section{ABSTRACT}

Aceh province based on BPS data 2017 has 1.2 million inhabitants have a livelihood as a farmer. Of this amount includes the number of farmers in each of the regency in Aceh. One of district that has a population of farmers that is the South Aceh Regency with a large producer of young plants, horticulture and plantation crops. Ruak Village is one of the villages in North Kluet Sub district with farmers in the form of coffee, corn, lime and rice. The villagers of Ruak have a livelihood as farmers, both farmers and farmers as well as daily laborers in the local farmers' business. Farmers in the village of Ruak are abundant every year. Based on the data that was successfully obtained during the survey that the farmers in the village of Ruak produced an average yield of 150 tons per year. Every year the village of Ruak lags behind to contribute to the community with the results of farmers produced by the farmers of the of Ruak village. The contribution of the farmers of the village of Ruak is not proportional to the celebrations obtained. This causes very high production costs, starting from the cost of plants, buying medicines, fertilizers, tools and daily payment instruments. The cost to plant to harvest is very high. Sometimes not comparable with the selling price of farmers. Prices are not in line with European expectations. Because the market price that has been determined by the parties cannot be negotiated by the farmers and because of the market price.

Copyright (C) 2018 Politeknik Aceh Selatan. All rights reserved.

\section{Introduction}

Indonesia is an agrarian country because most of its people have livelihood in agriculture or farming. Based on data obtained from Central Statistics Agency (BPS) in 2009, the number of farmers reached $44 \%$ of the total workforce in Indonesia or approximately 46.7 million people depend on the use of natural resources to meet the needs of life. The majority of the peasant population is working to meet the food needs for the entire population of Indonesia which is increasing in number each year.

The province of Aceh, based on BPS data in 2013, has 1.2 million inhabitants as farmers. Of this amount includes the number of farmers in each district spread across Aceh. One of the districts with the populations of farmers namely South Aceh District with the producers of crops, horticulture and plantations are quite large.

Ruak Village is one of the villages in North Kluet Sub district with farmers in the form of coffee, corn, lime and rice. Ruak majority villagers have livelihoods as farmers, both farmers and farmers as farmers in the local farmers' business. The results of farmers in Ruak village are abundant every year. Based on the data that was successfully obtained during the survey that the farmers of the village of Ruak produced an average yield of 150 tons per year. Every year the village of Ruak has the potential to contribute to meeting the food needs of the surrounding community with the results of farmers produced by farmers in the village of Ruak.

Ruak village farmers' contribution is not proportional to the income earned. This is due to very high production costs, starting from the price of buying plant seeds, buying medicinal plants, fertilizers, farmers' tools and paying for daily labor. The cost of planting to harvest is very high. 
Sometimes not comparable with the selling price of farmers. The sale price that is not in line with the farmers' expectations makes the farmers losses. Because the market price that has been determined by the agent cannot be negotiated by the farmers and agents because it is considered that the price is the market price.

The market price is set by the agent, they are the party who buys the farmer's yield and then resells it to the merchant or retailer. The role of agents in this case is very big role to determine the selling price of farmers. Determining, they determine the price for the benefit of them without considering the costs already borne by the farmers in the production process. The sale price of the farmer's products is the same for each other agent. Even the price is also equal to the price of farm produce in the local village market. In this case there has been a price monopoly made by them. So the condition is inevitably the farmer must sell the results of his farmers to them. Because farmers have no other choice. One side of the farmer needs to sell the farmers' produce to return capital during production. On the other hand, farmers must accept the prices offered by them, even though it is detrimental to farmers.

When the price of farmers' yields is static and monopoly in other areas the selling price of the farmer's harvest is very high. For example, the price of red chili in the area in North Kluet is Rp. 20,000 per kilo while in Tapaktuan and Banda Aceh Rp. 75,000 per kilograms (as a source of Tapaktuan market information). Based on info from Serambi Indonesia news, the price of red chili per kilogram in the market is Rp. 15,000 per kilogram. The deviation of the selling price by farmers and the consumer's purchase price is very far up to $300 \%$ even till $1200 \%$. Of course, in this case there is the price of transportation from farmers to consumers which is certainly not cheap but adjusted to the price of transport and distance between farmers and consumers, in addition there is a process of retailers to the consumer who made the price of agricultural products to be expensive but nevertheless the role of agents in this has been removed.

That phenomenon is what happened to the farmers of Ruak village so that research is needed to find a solution so that farmers do not feel disadvantaged. A method is needed to bring farmers to the real market. Markets without price monopolies, markets where farmers and traders are free to negotiate, healthy markets that benefit farmers and traders.

Methods used: The first stage analyzed the farmer's yield, type, selling method and selling price during the last 2 years, 2015-2016, and percentage of farmers selling price match compared to market price. This stage analysis will use a lot of secondary data and then the results of this stage analysis will be used as a reference to determine the percentage in 2017-2018. The next stage makes a projection of the percentage of the comparison of the selling price of the result with the market price and define the sales method approach that can increase the selling price of the farmer's yield as well as the identification of the market and the area of potential yield of the farm.

The planned activity plan that will be proposed is Ruak Village Government has map and statistics of farm produce, Ruak Village Government has map of potential area of farm produce, identify market need and map it, have sales method that stabilize high farmer selling price.

\subsection{The Problem Formulations}

Based on the background of the problem described, the formulation of the problem in this study is as follows.

1. Build a mobile-based farm warehouse application that is easy to use for farmers to upload farmer data.

2. Build the server as a database of farmer's data management.

3. Establish a monitoring system for sales transactions of results and statistics of farmers' harvests?

\section{Research Method and Tools}

\subsection{Situation Analysis and Research Location}

The location of the research was conducted in Ruak village and divided the farmers into farmer groups based on regional topology. The study was conducted on 10 points spread in agricultural areas, 10 points divided by the number of groups of farmers in the village. Each farmer 
group consists of farmers who are located around the area. One group of farmers consisting of several groups that were around the location of the area with the number of varied plants.

Furthermore, each farmer will be provided with a socialization of the advantages and disadvantages of using the application by explaining the phenomena that exist in the village and provide solutions to farm warehouse application that will be designed.

\section{Method of Approach}

The approach taken to overcome the problems that occur in Ruak village is by building a sales system application that is able to connect farmers with a broad market. A mobile-based app that can be installed easily on a smartphone. So as to enable farmers to take photos and upload them to the next server the buyers can easily see all the farmers who have been uploaded.

Furthermore, the buyer by installing the application first will be able to see all the farmers 'harvest that has been uploaded to the system, in addition to seeing the buyer can pick and choose all the farmers' harvests according to their desired needs. When the buyer has found the harvest needed next by using the application the buyer can use the system to order the desired harvest which is then followed by a direct bargaining process between the farmer and the buyer and if there is agreement then both parties can make transactions by giving money and gives the crops on both sides directly. When the buyer has ordered the crop on the application but does not make a transaction, the system automatically gives the notification that the item is still not sold, because the item status is only given within $1 \times 24$ hours. When a transaction occurs then the farmer to update the status of sales through the application.

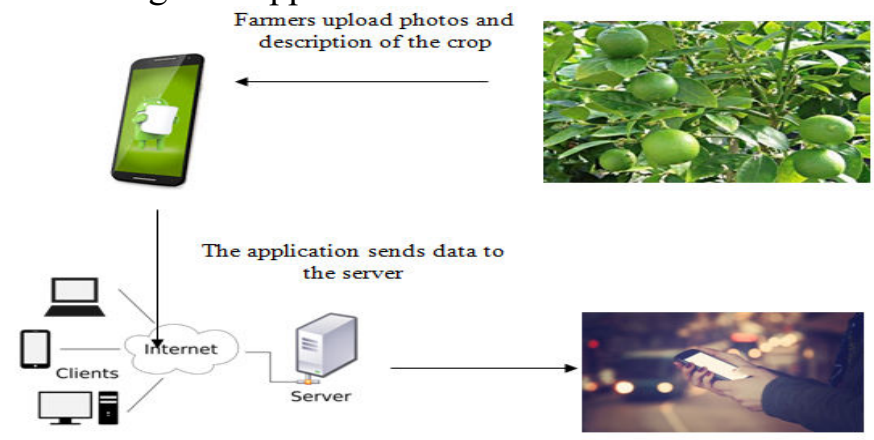

Figure 1. Illustration How Warehouse Farmer Application System Work

\section{Results and Discussions}

From this activity the results obtained that farmers in the location of North Kluet Sub-district has been able to use information and communication technology in seeking their needs for various information in managing the farm and indirectly the farmers in North Kluet District especially Ruak village and Kampung Tinggi can increase their competitiveness because of the way or information that they desperately need can be obtained with the holding of this program.

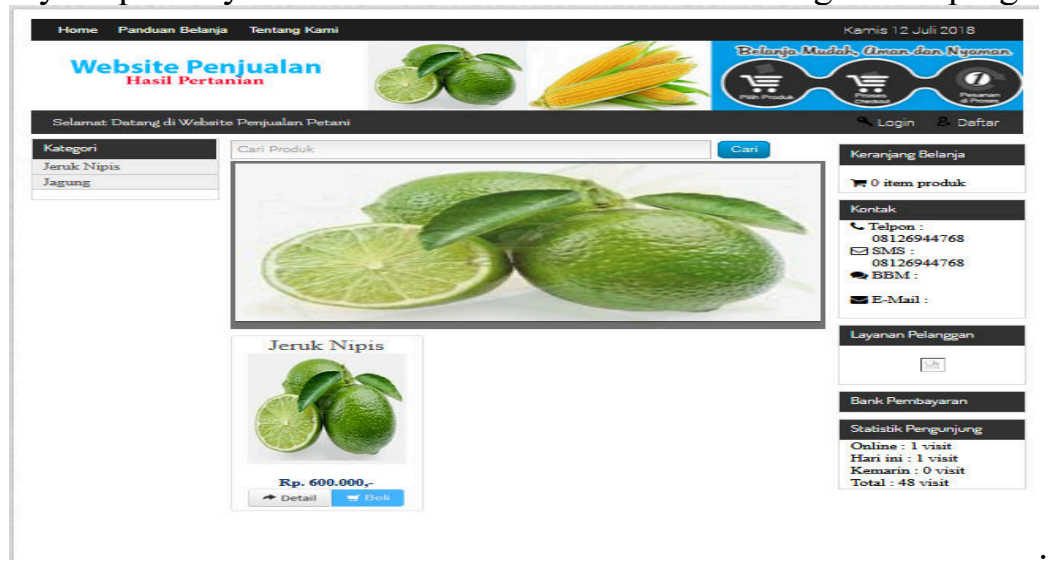

Figure 2. Search Results Information Availability of Farmers Harvest. 


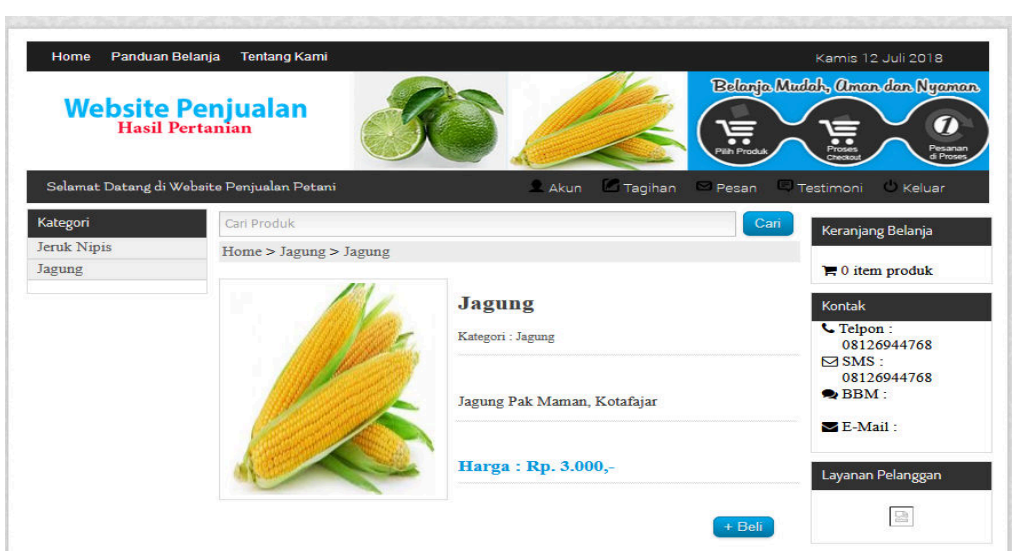

Figure 3. Search Results for Information on Farmer Harvesting Results.

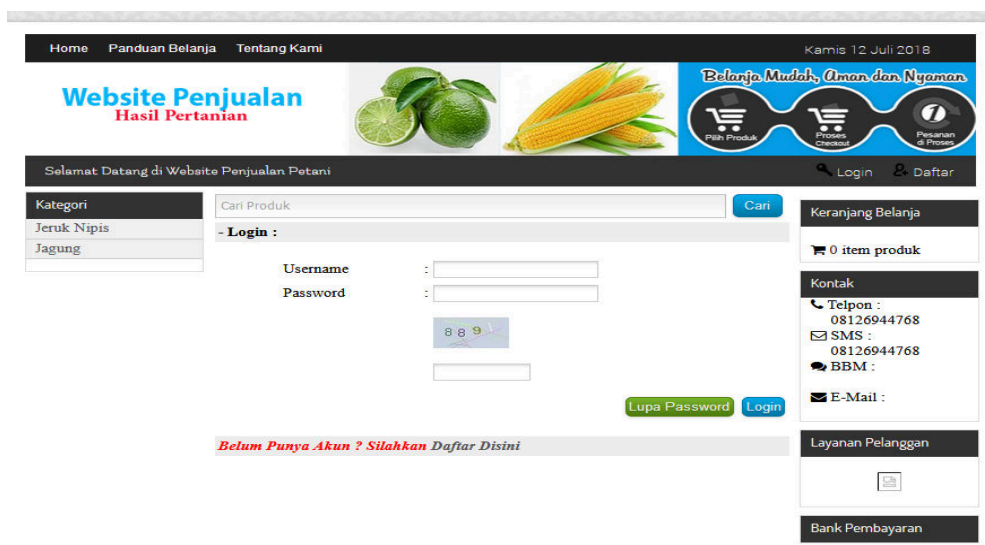

Figure 4. Customer Login or Buyer of Agricultural Products

From the results of the discussion of sales of agricultural products can be concluded:

1. Increased competitiveness of farmers in managing their agricultural products due to their increasing knowledge in using information technology to obtain all kinds of information.

2. Increased knowledge about how to find sites that sell their needs such as fertilizer and vegetable seeds and flowers, as well as the ability to implement Farmers Information System

3. The emergence of a sense of togetherness and cooperation in sharing information and the rise of mutual cooperation.

4. From me is as the executing team is the increase of my ability in communicating with the community that can be proved by my success in running this program which requires cooperation between me and the implementing member together with the community can also be done in other areas which also need these skills.

\section{Conclusions and Suggestions \\ A. Conclusion}

From the survey results from research programs in the form of socialization conducted in North Kluet District, South Aceh district Kampung Tinggi village, it can be concluded that farmers who have received socialization have been able to / can be used information technology in this case the internet to find information they need in managing their agricultural products and also have knowledge in implementing the Farmer Results Information System in selling results agriculture so that it will be able to improve the competitiveness of these farmers. 


\section{B. Suggestion}

From the survey results for this activity it can be suggested that to be able to optimize the desired results, there should be continued activities in the form of workshops on the use of information technology and the application of Farmer Results Information Systems in selling their agricultural products, and also this activity can also be done in other areas that also require these skills in the form of workshops the use of information technology, and also presumably this activity.

\section{References}

[1] Rahmat Hakim S, Ir Sutarto, M.Sc, "Java programming concepts and their application to make application software”, Elex Media, Jakarta, 2010.

[2] Nazrudin, "Intercession mobile application Programming smartphone and android-based tablet PC", Informatics, Bandung, 2014.

[3] Andriaty E, Setyorini E, "Availability of agricultural information technology resources in several districts in Java", http://ejurnal.litbang.deptan.go.id/, 2012.

[4] Suryaki Later, "Participation of farmers in the use of information and communication technology, Library Study Report” IPB, Bogor. 2014, 